Georgetown University Law Center

Scholarship @ GEORGETOWN LAW

2004

\title{
Pandemic Influenza: Public Health Preparedness for the Next Global Health Emergency
}

Lawrence O. Gostin

Georgetown University Law Center, gostin@law.georgetown.edu

This paper can be downloaded free of charge from:

https://scholarship.law.georgetown.edu/facpub/1819

32 J.L. Med. \& Ethics 565 (2004)

This open-access article is brought to you by the Georgetown Law Library. Posted with permission of the author. Follow this and additional works at: https://scholarship.law.georgetown.edu/facpub

Part of the Health Law and Policy Commons 


\section{Pandemic Influenza: Public Health Preparedness for the Next Global Health Emergency}

The threat posed by avian influenza appears to be rising, yet global and national health programs are preparing only fitfully. A lethal form of avian flu has rooted itself deeply into the poultry flocks of poor Asian countries that will have a hard time eradicating it. Every so often a sick bird infects a human, who usually dies from the encounter, and on rare occasions the virus seems to have spread from one person to another before the chain of infection dies out. All it would take to set off a raging global pandemic would be for the virus to mutate into a form that is readily transmissible among humans. ${ }^{\mathrm{I}}$

$\infty$ evere Acute Respiratory Syndrome (SARS) garnered a great deal of public attention because it was novel and its potential for spread was unknown. However, the SARS corona virus is significantly less virulent than pandemic influenza viral infections. The annual number of deaths for seasonal influenza is 36,000 people in the United States and 250,000500,000 worldwide. However, highly pathogenic influenza pandemics have occurred roughly 2-3 times per century, causing untold morbidity and mortality. ${ }^{2}$ The Spanish influenza pandemic of 1918 was believed to have caused over 20 million deaths in a world less than one-third the size of the current global population; ${ }^{3}$ modern epidemiologists now estimate that over 50 million people died. Moreover, these deaths did not occur primarily among infants and old people, as suggested by conventional wisdom. Approximately half the deaths were among people in the prime of their lives. As John Barry explains in his recent book, "One cannot know with certainty, but if the upper estimate of the death toll is true as many as 8 to 10 percent of all young adults then living may have been killed by the virus. And they died with extraordinary ferocity and speed."

There are three essential prerequisites for an influenza pandemic: (1) the identification of a novel viral subtype in animal populations such as swine or poultry, (2) viral replication causing disease in humans, and (3) efficient human-to-human transmission..$^{5}$ The species "jump" from animals to humans could occur through a process known as "reassortment." If a person is exposed to both animal and human viral infections, the "genetic mixing" could lead to a strain that is transmissible human-to-human, sometimes in ways that are highly resistant to vaccination or antiviral treatment. In-

Lawrence Gostin, JD, LL.D. (Hon.) is the John Carroll Research Professor of Law, Georgetown Unizersity; Professor of Public Health, the Johns Hopkins University; and Director, Center for Law $\boldsymbol{G}$ the Public's Health (CDC Collaborating Center Promoting Health Through Lai'). He is a lifetime elected member of the Institute of Medicine and serves on the IOM Board on Health Promotion and Disease Protection. 
fluenza $\mathrm{A}(\mathrm{H} 5 \mathrm{~N} 1)$, the viral strain responsible for the ongoing avian influenza outbreaks, has a worrying capacity to jump species, infecting cats and pigs, as well as, in the laboratory, ferrets and mice. ${ }^{6}$

Since 1997, the first two prerequisites - a novel viral strain in animals and transmission from animals to humans - have been met on numerous occasions. Although probable human-to-human transmission of a virulent strain of avian influenza has occurred, it has not yet been shown to be highly efficient.

From late 2003 through October 2004, outbreaks of highly pathogenic influenza $\mathrm{A}(\mathrm{H} 5 \mathrm{~N} 1)$ occurred among poultry throughout Asia ${ }^{7}$ and parts of North America. ${ }^{8}$ More than 200 million birds and other domesticated fowl have been culled or have died from the infection, including farms in the United States. ${ }^{9}$ The severe economic and trade impacts are illustrated by CDC and USDA orders for a ban on the import of all birds (Class: Aves) from affected areas in Southeast Asia. ${ }^{10}$ Similar restrictions were placed by countries in Europe and Asia on imports of U.S. poultry. During the A (H5N1) outbreaks of 2004 alone, there were 43 human cases, with extraordinarily high mortality rates; 31 of these individuals died. ${ }^{11}$ The avian influenza outbreaks have provoked fears of an influenza pandemic reminiscent of the great plagues in world history.12

The lack of reliable vaccine production, even for "routine" seasonal epidemics, has increased fears of lethal forms of influenza. The United States, for example, is experiencing extreme shortage of influenza vaccine for the 2004-05 season. Chiron Corporation - one of two manufacturers working on a vaccine for human bird flu - had its license to make conventional flu vaccine temporarily suspended by the British government in early October 2004. Chiron had been expected to provide 4648 million doses of the vaccine, about half of the nation's supply. Chiron is currently the subject of a criminal investigation and is facing a shareholder derivative lawsuit relating to the vaccine shortage. ${ }^{13}$ Responses to the shortage within the United States are varied, including the promulgation of emergency orders making it a misdemeanor to administer a flu shot to an individual not in an identified risk category, imposing penalties for price gouging, and the decision of various health insurers to cover an alternate (FluMist) vaccine. ${ }^{14}$ This is not the first time that the availability of influenza vaccines has been delayed, and, for decades, health experts have been issuing warnings concerning the fragility of the nation's vaccine supply and precarious dependence on a very low number of vaccine producers. ${ }^{15}$

There is now intense interest in influenza preparedness, with major planning initiatives being undertaken by the World Health Organization (WHO) and Insti- tute of Medicine (IOM). ${ }^{16}$ The potential for pandemic spread of a "fit" influenza strain leads to intriguing ethical and legal questions about public health interventions that could severely disrupt trade, economics, travel, and personal liberty. National and global public health agencies have mooted a wide range of interventions, asking such penetrating questions as: Should intrusive powers be exercised? At what stage in the outbreak should interventions commence and with what safeguards? How can vaccines and antiviral medications be produced reliably and delivered efficiently and fairly to large populations? Planning for the next pandemic includes not simply influenza but other novel infections, both naturally occurring and intentionally created. ${ }^{17}$

This article examines the principal therapeutic and non-therapeutic public health interventions for preventing or ameliorating pandemic influenza. (See Table). In each case, the hard, yet inevitable, legal and ethical questions are explored. Thereafter, the article provides several ethical values that can help evaluate public health interventions in anticipation of the next global health emergency.

\section{Public Health Interventions to Prevent or Ameliorate Pandemic Influenza}

Animal/Human Interchange

Scientists consider live bird markets, traveling poultry workers, and the movement of domestic poultry and fighting cocks to be the most likely vectors for spreading A (H5N1) from farm to farm and country to country. ${ }^{18}$ Consequently, a critical early preventive strategy is to control animal populations and prevent the species jump from animals to humans. Humans are highly vulnerable to animal infections due to the close proximity of animal and human populations in farming and distribution of poultry and meat. ${ }^{19}$ Strategies to diminish the risk include separation of animal and human populations; occupational health and safety in animal work (e.g., infection control and disinfection); and control of diseased or exposed animal populations (e.g., culling).

The international community faces daunting problems in implementing these strategies. International food safety law does not emphasize animal/human interchange. The Codex Alimentarius Commission, administered by the WHO and the Food and Agricultural Organization (FAO), regulates food hygiene and labeling. Codex's main concern is with the safety of the food supply and fair standards for international trade in food. ${ }^{20}$ Occupational health and safety rules are primarily found at the national level, and country safeguards are highly variable. Countries may have a selfish interest in continuing intensive farming and food distribution. These methods are cost-effective from an 


\section{Public Health Interventions: Purposes and Values}

\begin{tabular}{|c|c|c|c|}
\hline $\begin{array}{l}\text { Public Health } \\
\text { Intervention }\end{array}$ & $\begin{array}{l}\text { Purposes and } \\
\text { Objectives }\end{array}$ & $\begin{array}{l}\text { Strategies to Achieve } \\
\text { Public Health Purpose }\end{array}$ & $\begin{array}{l}\text { Ethicallissues and } \\
\text { Recommendations }\end{array}$ \\
\hline AnimallHuman Interchange & $\begin{array}{l}\text { Prevent "species jump" by } \\
\text { reducing proximity of } \\
\text { animals and humans }\end{array}$ & $\begin{array}{l}\text { Separation of animals and } \\
\text { humans; occupational health } \\
\text { and safety; control of } \\
\text { diseased animals }\end{array}$ & $\begin{array}{l}\text { Safeguard economic interests } \\
\text { in farming while protecting } \\
\text { the public's health }\end{array}$ \\
\hline Globol Surveillance & $\begin{array}{l}\text { Timely and systematic } \\
\text { monitoring of health } \\
\text { threats }\end{array}$ & $\begin{array}{l}\text { Cover all threats of global } \\
\text { importance; prompt country } \\
\text { reporting; use "small-world } \\
\text { networks" }\end{array}$ & $\begin{array}{l}\text { Ensure privacy safeguards } \\
\text { for individuals and protection } \\
\text { of groups }\end{array}$ \\
\hline Case Contoct Investigations & $\begin{array}{l}\text { Prevent spread of infection } \\
\text { to contacts of infected or } \\
\text { exposed persons }\end{array}$ & $\begin{array}{l}\text { Offer counseling, vaccination, } \\
\text { and/or treatment to infected } \\
\text { or exposed persons }\end{array}$ & $\begin{array}{l}\text { Conduct investigations with } \\
\text { sensitivity and respect for } \\
\text { individuals and their contacts }\end{array}$ \\
\hline Stable Vaccine Supply & $\begin{array}{l}\text { Assure stable vaccine } \\
\text { supplies for endemic and } \\
\text { pandemic influenza }\end{array}$ & $\begin{array}{l}\text { Create incentives for private } \\
\text { industry through public/ } \\
\text { private partnerships }\end{array}$ & $\begin{array}{l}\text { Balance public/private inter- } \\
\text { ests in intellectual property, } \\
\text { liability, and economic } \\
\text { investment }\end{array}$ \\
\hline $\begin{array}{l}\text { Vaccination and Medical } \\
\text { Treatment }\end{array}$ & $\begin{array}{l}\text { Prophylaxis, amelioration of } \\
\text { symptoms, and/or reduced } \\
\text { infectiousness }\end{array}$ & $\begin{array}{l}\text { Offer or require vaccination } \\
\text { or antiviral therapy to at-risk } \\
\text { or infected persons }\end{array}$ & $\begin{array}{l}\text { Balance bodily integrity with } \\
\text { common good; ensure fair al- } \\
\text { location of scarce resources; } \\
\text { make therapeutics available } \\
\text { to developing countries }\end{array}$ \\
\hline Community Hygiene & $\begin{array}{l}\text { Promote safer behaviors } \\
\text { among the population }\end{array}$ & $\begin{array}{l}\text { Health education and hand } \\
\text { washing, disinfection, masks, } \\
\text { ventilation, and avoidance } \\
\text { of contacts }\end{array}$ & $\begin{array}{l}\text { Balance health benefits with } \\
\text { costs and cultural sensiti- } \\
\text { vities; ensure equitable } \\
\text { access }\end{array}$ \\
\hline Travel and Border Controls & $\begin{array}{l}\text { Prevent cross-border spread } \\
\text { of infectious disease }\end{array}$ & $\begin{array}{l}\text { Travel advisories; border } \\
\text { restrictions; regulation of } \\
\text { conveyances; stop lists }\end{array}$ & $\begin{array}{l}\text { Health is salient; avoid un- } \\
\text { necessary restriction of } \\
\text { trade; safeguard against } \\
\text { discrimination }\end{array}$ \\
\hline $\begin{array}{l}\text { Decreased Social Mixing/ } \\
\text { Increased Social Distance }\end{array}$ & $\begin{array}{l}\text { ncrease social distance to } \\
\text { avoid rapid spread of infec- } \\
\text { tion in public settings }\end{array}$ & $\begin{array}{l}\text { Close civic activities, meeting } \\
\text { places, and transportation } \\
\text { systems }\end{array}$ & $\begin{array}{l}\text { Avoid heavy costs and dimin- } \\
\text { ished freedoms; deliver } \\
\text { services to the vulnerable }\end{array}$ \\
\hline Civil Confinement & $\begin{array}{l}\text { Separate the infected or } \\
\text { exposed from the healthy }\end{array}$ & $\begin{array}{l}\text { solation, quarantine, } \\
\text { cordon sanitaire }\end{array}$ & $\begin{array}{l}\text { Provide due precess; ensure } \\
\text { safe and humane setting; } \\
\text { consider compansation; gain } \\
\text { public's trust }\end{array}$ \\
\hline
\end{tabular}

economic perspective but do not necessarily result in safe practices to prevent animal-to-human transmission of disease.

Even if strong international health standards did exist, public health authorities would continue to face the problem of when to implement aggressive strategies such as culling. Premature interventions have profound economic implications affecting livelihoods and trade. However, weak or tardy interventions risk devastation to animal and human populations.

\section{Global Surveillance}

Surveillance of novel infections in humans offers early warning and provides an opportunity for a timely response. Experts recommend various surveillance activities, many of which were used in the 2003 SARS outbreaks: testing and screening; health questionnaires, notices, and declarations; fever monitoring (selfmonitoring, thermal scanning); and reporting and monitoring trends. ${ }^{21}$

Despite its importance, many countries do not conduct effective and timely surveillance. Prompt notification of an infectious disease threat can affect a country's tourism, trade, and prestige. Consequently, some governments do not respond promptly to WHO requests for information. Many countries, moreover, lack 
the infrastructure and resources to conduct surveillance. As a result, national surveillance activities are highly variable.

The International Health Regulations (IHR) are the principal rules covering the international spread of infectious diseases. The IHR, however, do not apply to influenza, but cover only three diseases: cholera, plague, and yellow fever. Instead, the WHO Influenza Surveillance Network was established in 1952 to identify viral strains to develop the next season's vaccinations.

The WHO is currently involved in intergovernmental negotiations to revise the IHR. The draft revised IHR, if adopted, would significantly strengthen international rules for surveillance. The rules would apply to all health threats of international importance; mandate country notifications; gather reports from unofficial sources; and provide for real-time event management. ${ }^{22}$ Global surveillance could further benefit from "small-world networks" consisting of health professionals, scientists, and non-governmental organizations continuously monitoring disease threats. ${ }^{23}$ It should be possible to supplement the surveillance provided by official sources with multiple public/private sources through the internet and other modern communication facilities.

Although surveillance is an essential public health strategy, even routine activities, such as reporting, affect privacy because government collects sensitive health information. Acute outbreaks can trigger more extreme measures such as continuous monitoring of certain populations such as health care workers, immigrants, and travelers. An outbreak of a novel influenza strain will inevitably raise questions about the appropriate scope of government surveillance and its affects on privacy. Surveillance needs to take place, therefore, with privacy safeguards in place.

\section{Case Contact Investigations}

Case contact investigation is a classical form of surveillance. It involves identifying infected or exposed persons and following their recent contacts. This provides an opportunity to interrupt the spread of infection. Persons exposed or infected can be offered antiviral therapy as a prophylaxis or treatment. Those who are infectious or potentially infectious can be separated from the healthy population.

Case contract investigation is ostensibly voluntary because the "index case" is under no formal obligation to reveal his or her contacts. Nevertheless, its use in sexually transmitted infections, including HIV/AIDS, has proved highly controversial. ${ }^{24}$ The index case may feel coerced into giving information, investigations pose privacy risks, and individuals may experience stigma and discrimination. These investigations, therefore, need to be conducted with sensitivity and respect for individuals and their family, friends, and associates.

\section{Vaccination: Scientific Innovation \\ in a Market Economy}

The dominant strategy for seasonal influenza is to use vaccinations for susceptible groups. Recommended vaccination of high-risk populations (e.g., children and the elderly) has become standard in developed countries, and mass vaccination could be recommended in the event of a more severe outbreak.

An influenza pandemic would necessitate "surge capacity" in the development and delivery of vaccines, yet the prospects for assuring large-scale access appear dim. Manufacturing capacity is sufficient to cover less that $5 \%$ of the world's population. Even highly industrialized countries such as the United States have difficulty assuring a stable vaccine supply. Evidence for the inability of the private sector to meet America's needs for vaccines has mounted, as demonstrated by sequential IOM reports..$^{25} \mathrm{~A}$ handful of major vaccine manufacturers exist in the world today; there were four times that number only 20 years ago. The problem is compounded with $\mathrm{A}$ ( $\mathrm{H} 5 \mathrm{~N} 1$ ) virus because standard methods for making influenza vaccines are ineffective for highly pathogenic strains.

Unreliability in the industry is fueled by a thicket of patent, liability, and financial concerns. Developing effective vaccines requires stable markets, venture capital, and economic incentives. Manufacturer investment costs may not be recouped if a pandemic does not occur or if intellectual property rights are in dispute. The industry could also be exposed to liability for adverse effects, even if lengthy clinical trials are undertaken (which would not be feasible in an emergency situation).$^{26}$ The unreliability of vaccine supply is problematic not only for civilian but also for military purposes. ${ }^{27}$ What is urgently needed is an effective public/private partnership to stimulate vaccine production. The IOM Council recommends the establishment of a National Vaccine Authority (NVA) to advance the development, production, and procurement of new and improved vaccines of limited commercial potential but of global public health need. ${ }^{28}$

\section{Therapeutic Interventions: Public Acceptance and Rationing a Scarce Public Good}

When vaccination is unavailable, public health authorities may use an antiviral medication such as Tamiflu. Antiviral therapy can be used for prophylaxis, alleviation of symptoms, and reduction of infectiousness. ${ }^{29}$ Antivirals, however, are costly, in short supply, and may be effective only if administered during the first two days following the onset of symptoms. 
Therapeutic interventions raise distinct ethical and legal concerns. Requiring competent adults to be vaccinated or treated for their own protection is an unpopular notion. Nevertheless, the law permits a reasonable interference with bodily integrity to prevent harm to the community. ${ }^{30}$

Although officials have the legal authority to compel vaccination or treatment to protect the public, the political and ethical dimensions underpinning such a decision are complex. There is a long history of opposition to vaccinations among certain sections of the population. ${ }^{31}$ Anti-vaccination sentiments are not always irrational because immunizations can pose risks, as well as confer benefits. Mass vaccination to avert an influenza epidemic can go horribly wrong, as occurred with swine flu in 1976. The CDC campaign to immunize the American population cost $\$ 134$ million and caused GuillainBarre Syndrome in some vaccine recipients. ${ }^{32}$

Vaccination or treatment can confer considerable benefit to the individual and, ultimately, to a population. Pandemic influenza would likely result in a paucity of vaccines and antiviral medications, raising the hard problem of fair allocation of scarce resources. Which ethical values should guide rationing decisions: private need (treatment of the sick); public need (prevention among vulnerable populations); maintenance of essential services (health care workers and "first responders"); or political influence (priority for those with political connections)? Justice may require that therapeutic interventions be used to benefit the most people possible, irrespective of their power or influence. This would militate toward the use of "public need" as the guiding ethical value. Therapeutics, therefore, would be used primarily for prevention and targeted to those who pose the greatest risk of transmission. The ethical value of "public need" might also require use of therapeutics for emergency workers to ensure maintenance of essential services and ongoing assistance to the public. This would place private need and political influence lower on the priority scale.

The global reality is that rich countries will have much less scarcity than poor countries. For example, Europe and the North America have over 90\% of the world's vaccine production capacity, but less than $10 \%$ of the global population. Countries with manufacturing capacities can be expected to reserve scarce supplies for their own populations, leaving poorer countries with the most acute vaccine shortages. The ethical question then arises as to whether developed countries would be expected to forego some of their precious stockpile of vaccines and antiviral medications for the sake of poorer countries experiencing a higher burden of morbidity and mortality from influenza? One might argue that it is in the richer country's self interest to do so since infectious disease can travel across the globe. Ethical analysis would prove difficult - do developed countries have an obligation to reduce the burden of disease in developing countries? If all human life has the same worth, then it may be ethically desirable to devote therapeutic resources to poor regions experiencing higher burdens of disease. This allocation of resources is likely to have the maximum beneficial effect on morbidity and premature mortality.

\section{Community Hygiene}

One of the most valuable means of infection control is also the least intrusive. Health education to promote safer behaviors such as hand washing, disinfection, masks, ventilation, and avoidance of contacts can be highly effective. Community hygiene, although largely uncontroversial, can impose costs (e.g., purchasing and distributing equipment) and cause social unrest (e.g., exaggerated concerns about health risks). Hygiene measures are also culturally sensitive - notice the difference in mask-wearing habits in Asia compared with North America and Europe.

Under what circumstances should public health authorities issue a national recommendation for aggressive hygiene measures given the costs and cultural expectations? Probably the most important concern would be the cost effectiveness of the hygiene measure. If a hygiene measure is clearly cost effective, then the public has the right to know how to adopt that measure in a safe way. Vulnerable members of the community may also need economic and technical assistance to ensure equitable access to essential hygiene measures. If a measure is not cost effective, then public health authorities have an obligation to inform the public about the lack of effectiveness and the risks. In some cases, such as the use of masks, the evidence for, or against, effectiveness may be unclear. In such instances, the principle of transparency may suggest that public health officials state honestly the lack of conclusive evidence, leaving the judgment to the individual.

\section{Travel and Border Controls}

One of the first instincts in the face of infectious disease threats is to protect national borders. Consequently, international or national health agencies may issue travel advisories, establish border restrictions, or regulate conveyances such as airplanes, ships, and trains. They might similarly use "stop-lists" to prevent specified individuals or groups from traveling. The draft revised IHR afford WHO considerable authority to regulate international travel and control borders.

Travelers legitimately claim the right to know health risks, but travel restrictions significantly affect tourism and trade. Consequently, travel advisories can be polit- 
ically charged, as were WHO advisories concerning SARS in Ontario, Canada. ${ }^{33}$ A delicate balance exists between trade and health. Indeed, the draft revised IHR direct WHO to "provide security against the international spread of disease while avoiding unnecessary interference with international traffic." ${ }^{34}$

When faced with the hard tradeoff between maximization of health or of trade, which should prevail and why? Arguably, health should take precedence over trade because of the fundamental value of human functioning and life itself. Despite the effects on tourism and trade, the public has a legitimate interest in knowing if there are health hazards in regions where they intend to travel. National and international public health agencies have an obligation to take steps that are necessary to prevent the spread of infection across borders. Thus, it would be legitimate to prevent travel of a person who poses a significant risk of transmission. What public health authorities may not do is use infectious disease control as a pretext for discrimination by targeting individuals based on their nationality, race, religion, or other status.

\section{Decreased Social Mixing/Increased Social Distance}

Most Americans take for granted their freedom to associate with others in a variety of social settings. Yet, public health authorities could restrict social mixing and increase social distance to avert a serious infectious disease threat. This might involve closures of civic activities (e.g., schools, workplaces), meeting places or large gatherings (e.g., sports events, theatres, and business meetings), and transportation systems (e.g., mass transit and airlines). The purpose behind restrictions on mixing is to prevent rapid spread of infection in settings where multiple people congregate.

The United States Constitution affords individuals the freedom to associate, but courts would likely defer to reasonable regulation of congregate settings to prevent transmission of infection. ${ }^{35}$ As with other interventions, closures entail heavy costs in lost revenue as well as in diminished freedoms. When an infectious disease outbreak deeply affects a society's everyday activities, public health authorities will have to cogently explain the need for such intrusive interventions and gain the public's confidence before implementing them. Critical legal and logistical questions loom: which authority has the power to close a venue; what criteria should be used to trigger a closure and when should the restriction be lifted; and how will services be delivered to vulnerable populations who may be at risk in an isolated residence or shelter?

Civil Confinement

The potential for a mass outbreak raises the specter of civil confinement to separate the infected or exposed from healthy individuals. This might entail isolation of infected persons, quarantine of exposed persons, or quarantine of a geographic area (cordon sanitaire). Civil confinements may take place in hospitals or other institutions, or in a person's home. New conceptions to separate the healthy from the infectious include "sheltering in place," which public health authorities analogize to a "snow day."

Many states modernized their public health statutes in the aftermath of the terrorist attacks on September 11th, 2001. ${ }^{36}$ Public health law reform is necessary to ensure that states and localities have the legal authority for isolation and quarantine. ${ }^{37}$ In order to meet constitutional standards, state law must have clear criteria for the use of civil confinement and must offer procedural due process. ${ }^{38}$

Civil confinement, of course, raises powerful civil liberties concerns. Not only is isolation or quarantine a deprivation of liberty, but enforcement can sometimes be intrusive. For example, during the SARS outbreaks, some countries used electronic bracelets, web cameras, and police to monitor and, at times, restrict the movement of individuals. It will also be important to ensure that judicial hearings are available, particularly in a mass outbreak. Isolation or quarantine will have to take place in a humane and habitable environment. Vulnerable persons need to be protected against re-exposure to infection, offered care and treatment, and guaranteed the necessities of life such as safe food and water. ${ }^{39}$ There may also be the need to consider compensation for lost work. Individuals are confined for the good of the community and have to forego their livelihood and other essential activities. Above all, public health authorities need to maintain the public's trust. To what extent would orders for civil confinement dissipate trust and reduce cooperation?

\section{Acting Under Conditions of Uncertainty: The Key Scientific and Social Questions} Influenza pandemic preparedness requires careful consideration of the public health strategy as well as the legal and ethical implications. Several key scientific questions loom: Are specific interventions cost effective? What combination of measures is most cost effective? During what phase of the pandemic should interventions be implemented? When should public health measures be discontinued?

Although many of the foregoing interventions have been widely used, many still lack adequate evidence of cost effectiveness. Even if individual interventions are known to be cost-effective, public health authorities will have to form a judgment as to the combination of measures that will be maximally effective. They will 
need to decide when to initiate and when to end an intervention.

The decision to intervene is difficult because public health authorities may be acting under conditions of scientific uncertainty. It may be unclear whether serologic tests are reliable, vaccines or treatment are safe and effective, and coercive interventions are acceptable to the population. To be effective, agencies may have to intervene at the earliest stages, before the threat level is clear. If interventions are well targeted and timed, then public health officials may prevent untold economic and human harm. However, if the interventions over-reach, officials will be accused of disregarding essential economic interests and fundamental human rights.

These scientific questions are important because public health interventions do not take place in a vacuum. They raise fundamental economic, political, and legal questions that need to be considered:

\section{Economics}

As mentioned earlier, public health interventions can have dire effects on the economy. They impede individual economic freedoms to travel and pursue a business or livelihood. They also affect local, national, and regional economies by impacting trade, travel, tourism, and agriculture. Countries may have built-in disincentives to conduct surveillance and response in an energetic and public way.

\section{Political}

Infectious disease outbreaks can have intense sociopolitical ramifications. Diseases affect a country's prestige as well as its economy, and the electorate may hold politicians accountable. As a result, political leaders may try to de-emphasize the threat or delay taking definitive action as occurred in numerous epidemics ranging from HIV/AIDS to SARS.

\section{Legal and Constitutional}

Infectious disease outbreaks take place in countries with vastly different legal and constitutional traditions. Public health planning may be undertaken within liberal democracies with full protection of human rights or they may take place in less democratic, perhaps more authoritarian, societies. During the SARS outbreaks, for example, countries behaved very differently in their response and protection of civil liberties. ${ }^{40}$ Infectious diseases tend to bring out the best and worst in societies. History demonstrates the potential for over-reaction, stigma, and discrimination in the face of a severe epidemic. ${ }^{11}$ Consequently, the legal and constitutional dimensions will be important in confronting a severe epidemic. ${ }^{42}$

\section{Ethical Values Underpinning Public Health Preparedness: The Cross-Cutting Issues}

Public health authorities have a mandate to protect the population's health. It is crucial, however, that they act ethically. Ethical values are usually too broad to precisely determine whether an activity is morally appropriate. Nevertheless, it ought to be possible to enunciate several ethical values that can inform public health practice, particularly in an emergency.

\section{Transparency}

The ethical value of transparency requires officials to make decisions in an open and fully accountable manner. Government officials must be willing to make clear the basis for public health measures. They should honestly and openly inform the public of what is known and not known; openly acknowledge when new evidence warrants reconsideration of policies; and educate the public about the goals of intervention and the steps taken to safeguard individual rights.

\section{Protection of Vulnerable Populations}

Diseases that may differentially affect segments of the population have usually imposed the additional burden of social opprobrium. Public health officials may inadvertently amplify the process as they conduct their surveillance activities. While they may not be able to prevent stigmatization, officials have an obligation to take steps to mitigate the suffering that may attend their efforts by underscoring the irrationality and inequity of ethnic stereotyping. Consultation with representatives of the communities most at risk will be important for instrumental reasons and as an expression of social solidarity. Individuals should feel a sense of participation in crucial decisions affecting their lives and communities. People place their trust in political leaders and, in return, they deserve due consideration and respect for their health and human rights.

\section{Fair Treatment and Social Justice}

Justice requires that the benefits and burdens of public health action be fairly distributed, thus precluding the unjustified targeting of already socially vulnerable populations. Equitable public health action is based on science and assures reasoned population-based policies. Procedural justice requires a fair and independent hearing for individuals who are subjected to burdensome public health action. Due process requirements are inherently important because fair hearings affirm the dignity of the person. Furthermore, due process is instrumentally important because it best assures accurate decision-making. 


\section{The Least Restrictiz'e Alternatize}

International human rights law is guided by the principle of proportionality: i.e., interventions should be necessary and proportional to the risk posed. ${ }^{43}$ Interventions should be the least restrictive alternative necessary to prevent or ameliorate the health threat. Requiring the least restrictive/intrusive alternative represents a means to impose limits on state interventions consistent with the traditions of privacy, freedom of association, and individual liberties. The standard does not require officials to utilize less-than-optimal interventions. However, they must choose the least intrusive alternative that can best achieve the health objective.

\section{The Public Health Paradox}

There is no way to avoid the dilemmas posed by acting without full scientific knowledge. Failure to move aggressively in the early stages of pandemic influenza can have catastrophic consequences. Actions that prove to have been unnecessary will be viewed as draconian and based on hysteria. The only safeguard is the adoption of ethical values in formulating and implementing public health decisions. Public health policy will reflect in a profound way the manner in which humane societies both implicitly and explicitly balance the common good with respect for personal rights.

\section{Disclaimer}

Professor Gostin was a member of WHO's consultation on influenza preparedness and is working with WHO on the revision of the International Health Regulations. He also participated in the IOM Workshop on preparing for the next pandemic. The views in this article do not necessarily reflect those of WHO or IOM. A shorter version of this article appears in the Hastings Center Report 34 (2004): 10-11.

\section{References}

1. Editorial, "The Menace From Avian Flu," New York Times, October 12,2004 , at A-30.

2. G. Kolata, "Genetic Material of Virus from 1918 Flu is Found,"New' York Times, March 21, 1997, at A-2.

3. J. Stevens, A.L. Corper, C.F. Basler, J.K. Taubenberger, P. Palese, and I.A. Wilson, "Structure of the Uncleaved Human H1 Hemagglutinin from the Extinct 1918 Influenza Virus," Science 303 (2004): 1866-70

4. J.M. Barry, The Great Influenza: The Epic Story of the Deadliest Plague in History (New York: Viking, 2004).

5. Board on Global Health, Institute of Medicine, Learning from SARS: Preparing for the Next Disease Outbreak (Washington, DC: National Academies Press, 2004)

6. K. Bradshere, L.K. Altman, "A War and a Mystery: Confronting Avian Flu," New York Times, October 12, 2004, at D-1.

7. Affected countries include Cambodia, China, Indonesia, Malaysia, Japan, Hong Kong, Laos, South Korea, Thailand, and Vietnam.

8. Centers for Disease Control and Prevention, "Outbreaks of Avian Influenza A ( $\mathrm{H} 5 \mathrm{~N} 1)$ in Asia and Interim Recommendations for Evaluation and Reporting of Suspected Cases--United States," Morbidity and Mortality Weekly Report 53 (2004): 97-100.

9. J. Dao, "Bird Flu Outbreak has Farmers Jittery," New York Times, February 16, 2004, at A-12.

10. Orders pursuant to 42 CFR 71.32b dated Feb. 4, March 10, and Sept. 28, 2004.
11. WHO, "Cumulative Number of Confirmed Human Cases of Avian Influenza $\mathrm{A}(\mathrm{H} 5 \mathrm{~N} 1)$ since 28 January 2004," at <http://www. who.int/csr/disease/avian_influenza/country/cases_table_2004_ 10_04/en/ > (last visited October 18, 2004).

12. CDC, "Outbreaks in Asia," at <http://www.cdc.gov/flu/avian/outbreaks/asia.htm > (last visited October 18, 2004); see H. Markel, When Germs Travel: Six Major Epidemics that Have Invaded America Since 1900 and the Fears They Have Unleashed (New York: Pantheon Books, 2004).

13. Pui-Wing Tam, "Chiron Receives U.S. Subpoena Over Flu Vaccine," The Wall Street Journal, October 13, 2004; Jerry Abejo, "Chiron Target of Shareholder Lawsuit," The Wall Street Jourmal, October 14, 2004.

14. Levine, "District to Issue Emergency Order Limiting Flu Shots," Washington Post, October 15, 2004, at B1; Haigh, "Bluementhal Wants Rell to Call Flu Vaccine Emergency," Associated Press, October 14, 2004; Mulder, "Some Insurers Will Pay for FluMist," The Post-Standard, October 14, 2004.

15. Grady, "With Few Suppliers of Flu Shots, Shortage Was Long in Making," New York Times, October 17, 2004.

16. R.J. Webby and R.G. Webster, "Are We Ready for Pandemic Influenza?" Science 302 (2003): 1519-22; World Health Organization, WHO Consultation on Priority Public Health Interventions Before and During an Influenza Pandemic (Geneva, Switzerland: WHO, 2004); see Board on Global Health, Institute of Medicine, supra note 5 .

17. R.A. Weinstein, "Planning for Epidemics: The Lessons of SARS," N. Engl.J. Med. 350 (2004): 2332-34.

18. D.G. McNeil Jr., "Experts Call Wild Birds Victims, Not Vectors," New York Times. October 12, 2004, at D-6.

19. E.J. Emanuel, "Preventing the Next SARS" New York Times, May 12,2003 , at A-25.

20. The Sanitary and Phytosanitary Measures Agreement is designed to promote free trade by ensuring that national measures to protect human, animal, or plant life are scientifically-based and not pretexts to protect domestic markets from international competition. See A.L. Taylor, D.W. Bettcher, S.S. Fluss, K. DeLand, and D. Yach, "International Health Instruments: An Overview," in R. Detels, J. McEwen, R. Beaglehole, and H. Tanaka, eds., Oxford Textbook of Public Health, 4th ed. (Oxford: Oxford University Press, 2002): at 359-86.

21. L.O. Gostin, R. Bayer and A.L. Fairchild, "Ethical and Legal Challenges Posed by Severe Acute Respiratory Syndrome: Implications for the Control of Severe Infectious Disease Threats," JAMA 290 (2003): 3229-37.

22. WHO Secretariat, Revision of the International Health Regulations, Geneva, Switzerland: World Health Organization, January 15, 2004, Publication EB113/3 Rev.1; see L.O. Gostin, "The International Health Regulations and Beyond," The Lancet: Infectious Diseases + (2004): 606-607.

23. L.O. Gostin, "International Infectious Disease Law: Revision of the World Health Organization's International Health Regulations," JAMA 291 (2004): 2623-27.

24. R. Bayer, K.E. Toomey, "HIV Prevention and the Two Faces of Partner Notification," American Journal of Public Health 82 (1992): 1158-64.

25. V.S. Mitchell, N.M. Philipose, and J.P. Sanford, eds., The Children's Vaccine Initiatice: Achieving the Vision (Washington, D.C.: National Academy Press, 1993); G.W. Pearson, ed., The Children's Vaccine Initiative: Continuing Activities (Washington, D.C.: National Academy Press, 1995).

26. K. Bradshere and L.K. Altman, "Experts Confront Major Obstacles in Containing Virulent Bird Flu," Net' York Times, September 30, 2004, at A-I.

27. Committee on a Strategy for Minimizing the Impact of Naturally Occurring Infectious Diseases of Military Importance, Protecting Our Forces: Improving Vaccine Acquisition and Availability in the U.S. Military (National Academy Press, 2002).

28. Statement from the IOM Council on Vaccine Development, November 5, 2001, available at <http://www.iom.edu/report. asp?id=5487> (last visited October 18,2004).

29. I.M. Longini Jr, M.E. Halloran, A. Nizam, and Y. Yang, "Con- 
taining Pandemic Influenza with Antiviral Agents," American Journal of Epidemiology 159 (2004): 623-33.

30. Jacobson $\tau$. Massachusetts, 197 U.S. 11 (1905); see L.O. Gostin, "Jacobson v. Massachusetts at 100: The Police Power and Civil Liberties in Tension," American Journal of Public Health (Forthcoming 2005).

31. S.E. Spier, "Perception of Risk of Vaccine Adverse Events: A Historical Perspective," I'accine 20, suppl. 1 (2001): S78-84.

32. R. Neustadt, H.V. Fineberg, The Epidemic That Never Was: Policy Making in the Sicine Flu Scare (New York: Vintage Books, 1983).

33. C. Krauss, "The SARS Epidemic: Toronto; Canada Increases Pressure on World Health Organization to Lift Travel Advisory," New York Times, April 26, 2003, at A-8.

34. Intergovernmental Working Group on the Revision of the International Health Regulations, World Health Organization, Working paper for regional consultations, Geneva (Switzerland): 2004

35. New York v. New St. Mark's Baths, 497 N.Y.S.2d 979 (1986).

36. L.O. Gostin, J.W. Sapsin, S.P. Teret, S. Burris, J.S. Mair, J.G. Hodge, Jr., and J. S. Vernick, "The Model State Emergency Health Powers Act: Planning and Response to Bioterrorism and Natu- rally Occurring Infectious Diseases," JAMA 288 (2002): 622-628.

37. L.O. Gostin, "Public Health Law in an Age of Terrorism: Rethinking Individual Rights and Common Goods," Health Affairs 21 (2002): 79-93.

38. Greene v. Edwards, 263 S.E.2d 661 (W.Va. 1980).

39. J. Barbera, A. Macintyre, L.O. Gostin, T. Inglesby, T. O'Toole, C. DeAtley, et al., "Large-Scale Quarantine Following Biological Terrorism in the United States: Scientific Examination, Logistic and Legal Limits, and Possible Consequences," JAMA 286 (2001): 2711-17.

40. J.W. Sapsin, T.M. Thompson, L. Stone, K.E. DeLand, "International Trade, Law, and Public Health Advocacy," Journal of Law, Medicine E Ethics 31 (2003): 546-56.

41. S.L. Gilman, "Disease and Stigma," Lancet 354, suppl. (1999): SIV15.

42. L.O. Gostin, Public Health Law: Power, Duty, Restraint (Berkeley and New York: University of California Press and Milbank Memorial Fund, 2000).

43. "The Siracusa Principles on the Limitation and Derogation Provisions in the International Covenant on Civil and Political Rights," Human Rights Quarterly 7 (1985): 3-14. 